\title{
CAN SEAWEED FARMING IN THE TROPICS CONTRIBUTE TO CLIMATE CHANGE THROUGH EMISSION OF SHORT-LIVED HALOCARBONS?
}

\section{Siew-Moi Phang ${ }^{1,2}$, Fiona Seh-Lin Keng ${ }^{1,3}$, Mithoo Singh Paramjeet-Kaur ${ }^{1,2}$, Yong-Ki- an Lim ${ }^{1}$, Noorsaadah Abd Rahman ${ }^{4}$, Emma C. Leedham ${ }^{5}$, Andrew D. Robinson ${ }^{6}$, Neil R.P. Harris ${ }^{6}$, John A. Pyle ${ }^{6}$, William T. Sturges ${ }^{5}$}

${ }^{1}$ Institute of Ocean and Earth Sciences (IOES), University of Malaya, 50603 Kuala Lumpur, Malaysia.

${ }^{2}$ Institute of Biological Sciences, Faculty of Science, University of Malaya, 50603 Kuala Lumpur, Malaysia.

${ }^{3}$ School of Allied Health Sciences, SEGi University, 47810 Petaling Jaya, Malaysia.

${ }^{4}$ Department of Chemistry, Faculty of Science, University of Malaya, 50603 Kuala Lumpur, Malaysia.

${ }^{5}$ School of Environmental Sciences, University of East Anglia, Norwich NR4 7TJ, England.

${ }^{6}$ Centre for Atmospheric Science, University of Cambridge, Cambridge CB2 1EW, England.

*Corresponding author: phang@um.edu.my

\begin{abstract}
Volatile halocarbons form a major source of halogen radicals in the atmosphere, which are involved in the catalytic destruction of ozone. Studies show that marine algae release halocarbons, with $70 \%$ of global bromoform produced by marine algae (Carpenter et al., 2000). The role of halocarbons in algae is linked to their use as defense against epiphytes and grazing as well as scavengers of strong oxidants (Nightingale et al., 1995). Halocarbon release rates are higher for tropical algae than temperate species (Abrahamsson et al., 1995). The Maritime Continent is a major contributor to emissions of short-lived halocarbons and their transport to the stratosphere due to deep convection. The Coral Triangle situated in the Maritime Continent, is a centre for seaweed farming. The following discusses the potential impact of tropical seaweed emissions of halogenated compounds to climate change.
\end{abstract}

\begin{abstract}
ABSTRAK Halokarbon mudah meruap adalah sumber utama radikal halojen dalam atmosfera, yang terlibat dalam pemusnahan lapisan ozon. Kajian menunjukkan bahawa alga melepaskan halokarbon, dan 70\% bromoform dihasilkan oleh alga marin (Carpenter et al., 2000). Peranan halokarbon dalam alga berfungsi sebagai pertahanan terhadap epifit dan 'oxidant scavengers' yang kuat (Nightingale et al., 1995). Kadar pengeluaran halokarbon adalah lebih tinggi untuk alga tropika daripada spesies sederhana (Abrahamsson et al., 1995). Benua Maritim adalah pengeluar utama bagi halokarbon jangka hayat pendek dan pengangkutannya ke stratosfera disebabkan perolakan dalam Segitiga Terumbu Karang yang diletak dalam Benua Maritim, adalah pusat pengkulturan rumpai laut. Kertas ini membincangkan impak daripada pengeluaran halokarbon daripada rumpai laut terhadap perubahan iklim.
\end{abstract}

(Keywords: Volatile halocarbons, Marine algae, Seaweed farms, Maritime Continent, Climate change)

\section{INTRODUCTION}

\section{Natural and Farmed Seaweeds in the Maritime Continent.}

The Maritime Continent as used by meteorologists and oceanographers to describe the interaction between ocean and land, refers to the region between the Indian and Pacific Oceans including the archipelagos of Indonesia, Borneo, New Guinea, the Philippine Islands, the Malay Peninsula, and the surrounding seas (Commonwealth of Australia 2015, Bureau of Meteorology). The Coral Triangle (Figure 1) is a marine area comprising more than $100,000 \mathrm{~km}$ coastline and a marine area of 6 million $\mathrm{km}^{2}$, situated within the Maritime Continent, and is bordered by six nations, namely Indonesia, Philippines, Malaysia, Solomon Islands and Timor Leste (Phang et al., 2010). The Coral Triangle is situated in one of the mega-diversity regions of the world, especially in terms of marine biodiversity. The long coastlines together with the abundance of islands support a rich diversity of marine algae. Checklists of the seaweed flora of the region is incomplete but available publications indicate that the Philippines has the highest diversity with 949 taxa including 61 taxa of Cyanobacteria, 522 taxa of Rhodophyta, 154 taxa of Ochrophyta (Phaeophyta) and 212 taxa of Chlorophyta (Ganzon-Fortes et al., 2012). Verheij and Prud' home van Reine (1993) reported a total of 199 taxa with 80 taxa of Chlorophyta, 36 taxa of Phaeophyta and 83 taxa of non-coralline and 35 taxa of coralline Rhodophyta for the Spermonde Archipelago. An updated checklist (Pham et al., 2011) of Singapore algae comprised a total of 1,054 species, varieties and forms of algae, both freshwater and marine. Lewmanomont and Ogawa (1995) published a photographic guide to the common seaweeds and seagrasses of Thailand, comprising 49 taxa of Rhodophyta, 41 taxa of Chlorophyta, 26 taxa of Phaeophyta and 2 taxa of Cyanophyta. Updated records for Malaysia give a total of 355 taxa 
belonging to the Cyanophyta ( 8 taxa), Chlorophyta (87), Rhodophyta (156) and the Phaeophyta (90) (Phang 2015 unpublished data). A total of 827 species comprising 180 Chlorophyta, 147 Phaeophyta, 412 Rhodophyta and 88 Cyanophyta were compiled from various published sources for Vietnam (Nguyen et al., 2013). In general the red seaweeds dominate in terms of diversity followed by the brown and green seaweeds.

The Coral Triangle also represents an excellent example of a tropical region where intensive seaweed farming takes place (Hurtado et al., 2014). More than 120 million people live within the Coral Triangle but these populations are amongst the poorest in the region, and seaweed farming is an important contributor to poverty eradication (WWF, 2015). Seaweed farming is one of three priority development areas for the agriculture sector in Malaysia, and the main seaweeds farmed in the Coral Triangle, belong to the red seaweed genera Kappaphycus Doty and Eucheuma J. Agardh, with minor contributions from Gracilaria farmed in Indonesia. In 2007, the global production of the carrageenophytes (Kappaphycus and Eucheuma) was more than 200,000 metric tonnes (MT) dry weight (DW) (Neish, 2008), which sold for between USD800 to 1200 per MT DW. In 2009, the total production of Kappaphycus within the Coral Triangle was 200,000 MT DW, and Papua New Guinea joined in with trial plots in the Alatau area in August 2010 (Phang et al., 2010). In 2010, 5,623,000 MT wet weight (WW) of the carrageenophyes were produced globally, with Indonesia (60.5\%), the Philippines $(31.9 \%)$, Malaysia $(3.7 \%)$, Tanzania $(2.3 \%)$ and China (1.1\%) taking the lead (Hurtado et al., 2014). Production in the Coral Triangle is set to increase based on the potential cultivable area(s); Indonesia has 17,000 islands with $52,716 \mathrm{~km}$ coastline; Philippines has 7000 islands with $36,289 \mathrm{~km}$ coastline while in Malaysia, about 8,000 ha is under cultivation, with another 43,000 ha allocated for future farms. In 2012, the top carrageenophyte producers were Indonesia $(6,514,864$ MT WW; USD 1,348 million); Philippines (1,751,971 MT WW); USD 231.8 million), Malaysia (331,490 MT WW; USD 64.4 million); Solomon Islands (13,000 MT WW.; USD 530,000) and Timor Leste (15,000 MT WW; USD 113,000) (FAO, 2014). Vietnam produced 234,600 MT WW worth USD 117.3 million). In 2012, Tanzania produced 15,088 MT DW with a value of USD 4.25 million (Msuya et al., 2014). Kappaphycus sold for USD 0.51 per kg DW, twice that for Eucheuma. Latin America, comprising Argentina, Brazil, Chile, Mexico and Peru, with a total marine area of about $59,591 \mathrm{~km}^{2}$, produce mainly Gracilaria species, with Kappaphycus and Eucheuma being trial planted (Hayashi et al., 2014). Other seaweeds like Sarcothalia, Mazzaela, Gigartina, Chondracanthus and Gelidium are harvested from natural populations.

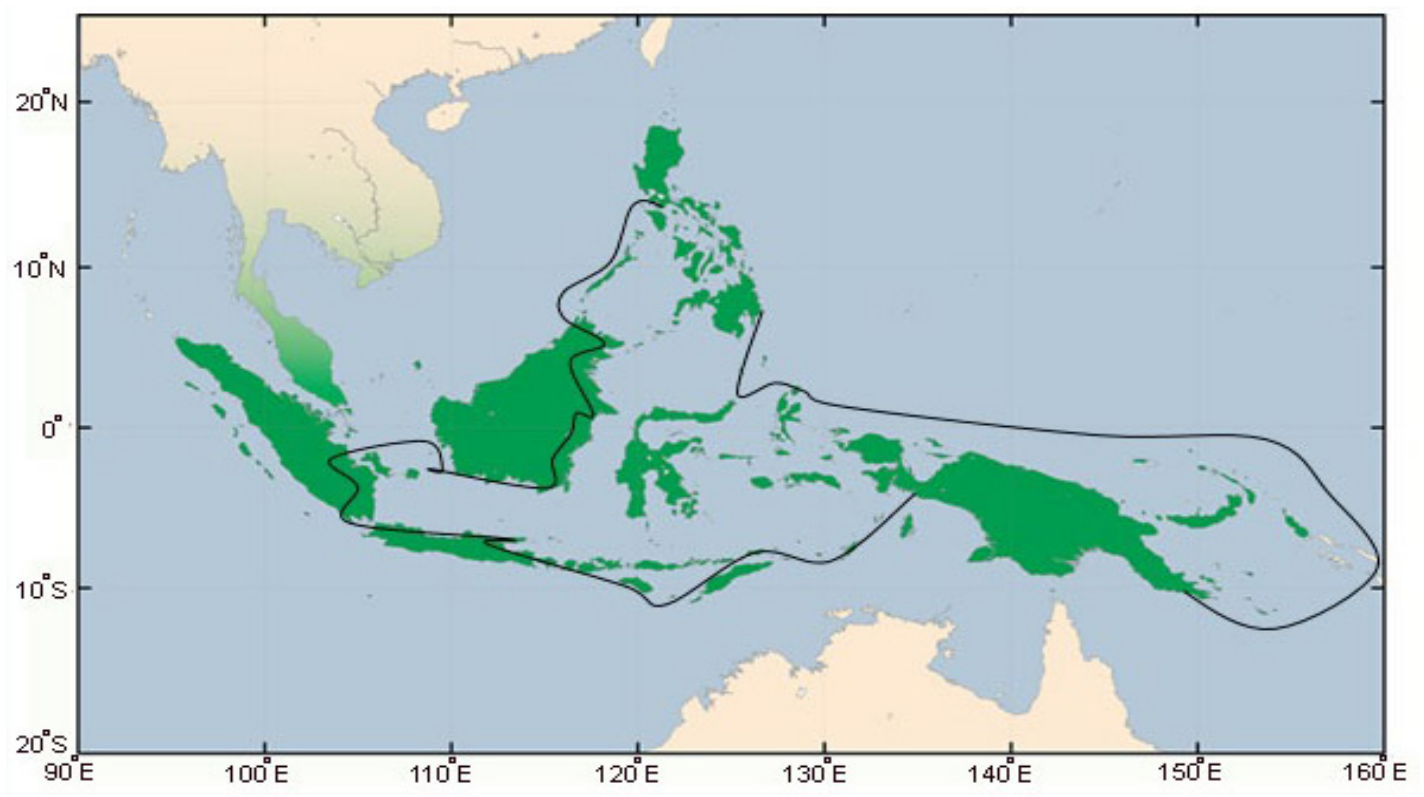

Figure 1. The Maritime Continent and the Coral Triangle (bordered in black) (Source: http://www.bom.gov.au/climate/about/tropics/maritime-continent.shtml) 


\section{Marine Emissions of Halogenated Compounds in the Tropics}

The tropics, including Southeast Asia, have rapidly industrialised, resulting in increased contributions to air pollution. Natural and anthropogenic emissions influence atmospheric composition, climate and air quality. Climate change may in turn affect natural emissions especially those from the terrestrial and marine ecosystems. It has been shown that halogens in the form of very short-lived halocarbons (VSLH) and volatile organic compounds (VOC) may affect the oxidizing capacity of the troposphere. These compounds when transported up into the troposphere and stratosphere, undergo photolysis and the halogens which are released, result in ozone depletion in the stratosphere and influence climate change (Aschmann et al., 2009). Examples are brominated and chlorinated halocarbons which indirectly affect temperature (Forster and Joshi, 2005) by ozone depletion. High sea surface temperatures coupled with high bioproductivity in tropical oceans lead to deep convection forces which transfer these compounds to the atmosphere (Levine et al., 2007). While the tropical and sub-tropical Pacific Ocean has been shown to be an important source of VSLH, information in the tropical Southeast Asian region is currently being gathered through active multinational collaborations (Pfeilsticker et al., 2013). This is important as the transport of the short-lived species to the tropical tropopause is very rapid over the Maritime Continent (Levine et al., 2008). Of the VSLH compounds, the reactive bromine and iodine species originate mainly from organic halocarbons from macroalgae (seaweeds) (Carpenter and Liss, 2000). Chloroform $\left(\mathrm{CHCl}_{3}\right)$ is also produced naturally by seaweeds (Nightingale et al., 1995). Rainforests may also contribute to the emissions. Pyle et al. (2011a) reported that levels of bromoform $\left(\mathrm{CHBr}_{3}\right)$ differed between two monitoring sites in Sabah, one in the rainforest at Danum Valley and the second at Kunak, a coastal town. Levels at Kunak were higher and analysis confirmed that the air had traversed biologically rich oceanic and coastal areas. A survey showed that natural seaweed populations at Kunak comprised species of brown seaweeds (Sargassum, Dicyota, Hormophysa and Padina), red seaweeds (Amphiroa, Laurencia, Gracilaria, Hypnea) and green seaweeds (Caulerpa, Halimeda, Anadymene, Neomeris) (Pyle et al., 2011b). Sargassum siliquosum and Sargassum myriocystum were dominant. Seaweed farms of Eucheuma and Kappaphycus are abundant in the region (Phang et al., 2010). It has been shown that Eucheuma denticulatum produces the halocarbons $\mathrm{CHBr}_{3}$ and diiodomethane $\left(\mathrm{CH}_{2} \mathrm{I}_{2}\right)$ (Mtolera et al., 1996).

\section{Halocarbon Production}

Halocarbons comprise compounds consisting of a carbon atom bonded to one or more halogens. While long-lived halocarbons contribute significantly to the stratospheric halogen load, it may be the short-lived halocarbons with lifetimes of six months or less that are important in the contribution of free halogen radicals to the stratosphere (Laube et al., 2008). Examples of long-lived halocarbons include the chlorofluorocarbons (CFCs), hydrochlorofluorocarbons (HCFCs), halons, carbon tetrachloride $\left(\mathrm{CCl}_{4}\right)$, methyl chloroform $\left(\mathrm{CH}_{3} \mathrm{CCl}_{3}\right)$ and methyl chloride $\left(\mathrm{CH}_{3} \mathrm{Cl}\right)$. These gases are predominantly anthropogenic (WMO, 2007). Although natural processes such as volcanic eruption could release some of these long-lived compounds e.g. $\mathrm{CCl}_{4}, \mathrm{CH}_{3} \mathrm{Cl}$ (Frische et al., 2006), the contribution of CFCs and few other long-lived compounds through natural processes are negligible (Martinerie et al., 2009). In an attempt to minimize and prevent further loss of the stratospheric ozone, the Montreal Protocol on Substances that Deplete the Ozone Layer (1987) and its subsequent amendments saw the complete phase-out of CFCs, halons, and carbon tetrachloride. As a result of such treaties, there were significant declines in the surface concentrations of the CFCs and carbon tetrachloride globally (WMO, 2011). However, due to the long atmospheric lifetime of these compounds, a time lag exists between the decline in the source gas emissions and the actual concentration of such gases existing in the atmosphere (Martinerie et al., 2009). This would mean that the 'complete loss' of such compounds in the atmosphere would take up years and even centuries depending on the lifetime of gases, which in turn rely on the oceanic and terrestrial uptakes, photolysis and hydroxyl radical oxidation of the particular compound (WMO, 2011). The majority of iodinated short-lived compounds are released through natural processes especially from the ocean (WMO, 2011) but anthropogenic release of several iodinated compounds including $\mathrm{CH}_{3} \mathrm{I}$ through biomass burning (Mead et al., 2008) and for use as fumigant (UNEP/ TEAP, 2010) had been reported. Enhanced emissions of methyl iodide $\left(\mathrm{CH}_{3} \mathrm{I}\right)$ could be caused by increased sea surface temperature (Yokouchi et al., 
2008) and abiotic chemical mechanism stimulated by dust deposition (Williams et al., 2007), oceanic sources may include phytoplankton (Hughes et al., 2006) and seaweeds (Carpenter et al., 2000). Carpenter et al. (2000) reported $\mathrm{CH}_{2} \mathrm{I}_{2}$ as the dominant iodocarbon released by temperate brown species, namely Laminaria digitata, Laminaria saccharina, Ascophyllum nodosum, Fucus vesiculosus and Fucus serratus that were studied. The Laminarias were reported as the strongest accumulators of iodide - the accumulated form of iodine, among all living organisms to date (Ar Gall et al., 2004). This iodide was also found to be the simplest inorganic form of antioxidant (Küpper et al., 2008). Terrestrial sources of chlorinated and brominated compounds include vegetation, soil production, biomass burning, mangroves, fungal processes, salt marshes, rice paddies and peatlands which also contribute to the emission of short-lived halocarbons (Montzka et al., 2010; Laturnus et al., 2002).

The role of halocarbons in algae is linked to their use as defense against epiphytes and grazing as well as scavengers of strong oxidants (Paul et al., 2006; Ohsawa et al., 2001; Manley, 2002). Halocarbons emitted by macroalgae have anti-herbivory (McConnell and Fenical, 1977) and antibacterial activities (Neidleman and Geigert, 1986). Bromoform $\left(\mathrm{CHBr}_{3}\right)$ emissions in seawater comparable with the amount usually emitted by coralline red algae have been found to inhibit growth of microscopic marine algae, specifically the diatoms. Further investigation showed that the surface of coralline algae that produced $\mathrm{CHBr}_{3}$ and $\mathrm{CH}_{2} \mathrm{Br}_{2}$ were void of diatoms whereas the surface of dead corallines which did not have any halocarbon emission were filled with epiphytic diatom populations (Ohsawa et al., 2001). Choo et al. (2004) reported that Enteromorpha ahlneriana have less epiphytic infestations and grazers on its surface unlike Cladophora glomerata, due to higher production of hydrogen peroxide and emission of brominated volatile halocarbons in the former. Other publications from La Barre (2010), Paul and Pohnert (2010) and Weinberger et al. (2007) have further confirmed that a wide range of halogenated compounds are indeed emitted by algae as a defense mechanism; specifically for protection against grazing, oppressing microalgal epiphytes and keeping bacterial infection at a minimal level.

How do seaweeds produce halogenated compounds? The production of volatile polyhalogenated compounds is linked to haloperoxidase enzyme activity in the seaweed (Manley, 2002), responsible for countering the oxidative stress in seaweeds resulting from the build-up of reactive oxygen species from metabolic responses like photosynthesis (Dummermuth et al., 2003). These reactive oxygen species are reduced to produce hydrogen peroxide which is used in the halogenation of organic compounds by the enzymes (Manley, 2002). Haloperoxidases especially the bromoperoxidase, are produced by green, red and brown seaweeds (Butler and Walker, 1993; Carpenter et al., 2000). In the brown seaweeds, haloperoxidases are linked to uptake of seawater iodide, which provides a strong antioxidant defense to the seaweed (Küpper et al., 1998). The emission of methyl halide was suggested to involve the S-adenosylmethionine (SAM): halide ion methyl transferase reactions, which is not dependent on presence of hydrogen peroxide (Ohsawa et al., 2001; Wuosmaa and Hager, 1990).

\section{Halocarbon Emission by Tropical Algae}

Lovelock (1975) first reported increased levels of $\mathrm{CH}_{3}$ I over kelp beds. Later studies reported different types of volatile halocarbon compounds released by seaweeds and microalgae (e.g., Hughes et al., 2006; Tokarczyk and Moore, 1994) by temperate and polar seaweeds. Eucheuma denticulatum, a tropical red seaweed cultivated as a source of carrageenan, was reported to release bromoform, diiodomethane, dibromochloromethane, perchloroethylene, chloroiodomethane, chloroform, sec-butyl iodide, methyl iodide, methylchloroform, carbon tetrachloride, trichloroethylene and butyl iodide (Mtolera et al., 1996). The dominant volatile halocarbons (VHC) were bromoform $\left(310 \pm 25 \mu \mathrm{g} \mathrm{kg} \mathrm{DW}{ }^{-1} \mathrm{~h}^{-1}\right)$ and diiodomethane $\left(182 \pm 9 \mu \mathrm{g} \mathrm{kg} \mathrm{DW}^{-1} \mathrm{~h}^{-1}\right)$. High irradiance and carbon dioxide deficiency increased the halocarbon production through induction of hydrogen peroxide synthesis (Mtolera et al., 1995; Mtolera et al., 1996). Another tropical carrageenophyte Kappaphycus alvarezii was shown to release hydrogen peroxide into the seawater under stress from high light, low temperature and in the presence of thylakoid electron transport system inhibitor (Barros et al., 2006). This occurred to avoid accumulation of the harmful peroxide that leads to oxidative lesions in the tissue. However, this prevented immediate induction of the $\mathrm{H}_{2} \mathrm{O}_{2}$-scavenging activities of catalases and ascorbate peroxidases, but is useful for long-term adaptation to a stressed environment. Species of the red agarophytes, Gracilaria, release volatile halogenated organic compounds (VHOC) 
involving vanadium-dependent haloperoxidases (Weinberger et al., 2007). While Gracilaria sp. produces iodo-bromoperoxidases releasing brominated and iodinated compounds, Gracilaria chilensis expresses a selective haloperoxidase to selectively release chlorinated compounds. A commonly found Malaysian red seaweed, Laurencia has been reported to produce a variety of halogenated compounds. Laurencia majuscula produces elatol, iso-butanol and rogiolol as secondary metabolites that served as antibacterial compounds (Vairappan, 2003; Vairappan and Phang, 2005). L. similis produced polybrominated indoles, namely 2,3,5,6-tetrabromoindole and 1-methyl-2,3,5,6-tetrabromoindole (Vairappan et al., 2004), also with antibacterial activities. Other halogenated seaquiterpenes identified from Malaysian Laurencia spp. included the brominated metabolites tiomanene, acetylmajapolene $\mathrm{B}$, majapolene $\mathrm{A}$, majapolene $\mathrm{B}$, three halogenated sesquiterpenes and two halogenated C15 acetogenins (Vairappan et al., 2008).

Marine algae were reported to be significant natural sources of olefins in the oceans. Seaweeds were collected from their natural habitats in tropical, sub-tropical and temperate regions for determination of the production rates of two chlorinated ethenes, trichloroethylene and perchloroethylene (Abrahamsson et al., 1995). The production rates were $0.22-3,400 \mathrm{ng} \mathrm{g}^{-1} \mathrm{FW} \mathrm{h}^{-1}$ and $0.0026-8.2$ $\mathrm{ng} \mathrm{g}^{-1} \mathrm{FW} \mathrm{h}^{-1}$ for trichloroethylene and perchloroethylene respectively. Two species, Asparagopsis taxiformis (tropical to sub-tropical) and Falkenbergia hillebrandtii (sub-tropical) gave highest production rates. It was further shown that the history and conditioning of an alga prior to analysis are important factors influencing the halocarbon release (Abrahamsson and Pedersén, 2000).

Dimethyl sulphide (DMS) is another trace gas formed in marine waters by biological (algae) and photochemical processes (Liss, 2007). Dimethylsulphonioprionate (DMSP) serves as an osmolyte and cryoprotectant in marine species and is the precursor to the DMS. DMS affects climate by serving as cloud condensation nuclei. In a survey of corals and benthic algae in the Great Barrier Reef of Australia, DMSP concentrations ranged from 21 - 3831 fmol DMSP zooxanthellae ${ }^{-1}$ in corals and $0.16-2.96 \mathrm{nmol}$ DMSP $\mathrm{cm}^{-2}$ for benthic seaweeds (Broadbent et al., 2002), indicating the importance of these organisms as reservoirs of DMSP. Another trace gas, isoprene (2-methyl-1,3-butadiene) is pro- duced by marine phytoplankton (Shaw et al., 2003; Broadgate et al., 1997), with pathway for isoprenoid biosynthesis reported for the green microalgae Chlorella fusca, Chlamydomonas reinhardtii and Scenedesmus obliqus, hot spring Cyanidium caldarium and the blue-green alga Synechocystis (Disch et al., 1998). In 2004, Broadgate et al. reported that marine macroalgae like Chondrus crispus, Asparagopsis armata, Ulva intestinalis, Laminaria digitata, Fucus vesiculosus, emit isoprene. Production is related to species, temperature as well as irradiance.

Halocarbon release rates are higher for tropical algae than temperate species. The fringing coral reef at Cape Rachado, west coast Peninsular Malaysia, is dominated by Phaeophyta (brown seaweeds). Regular monitoring of the seaweed community revealed that species diversity ranged from 69 to 81 species with biomass ranging from 17 to 104 g.m ${ }^{-2}$ (Phang, 1995). The seaweed communities at the intertidal reef are exposed to varying environmental conditions linked to the change of tides and the seasons. The three dominant brown seaweeds, namely Sargassum binderi Sonderex (J. Agardh), Padina australis (Hauck), and Turbinaria conoides (J. Agardh) (Kützing) were shown to emit eight volatile halogenated compounds (iodomethane $\left(\mathrm{CH}_{3} \mathrm{I}\right)$, diiodomethane $\left(\mathrm{CH}_{2} \mathrm{I}_{2}\right)$, bromochloromethane $\left(\mathrm{CH}_{2} \mathrm{BrCl}\right)$ bromoiodomethane $\left(\mathrm{CH}_{2} \mathrm{BrI}\right)$, dibromomethane $\left(\mathrm{CH}_{2} \mathrm{Br}_{2}\right)$, tribromomethane $\left(\mathrm{CHBr}_{3}\right)$, bromodichloromethane $\left(\mathrm{CHBrCl}_{2}\right)$, and dibromochloromethane $\left(\mathrm{CHBr}_{2} \mathrm{Cl}\right)$. Laboratory studies showed that the release of halogenated compounds by the three dominant brown seaweeds, as detected using a purge-and-trap sample preparation system with a gas chromatograph and mass-selective detector, was influenced by irradiance. Correlations were also observed between emissions of certain halocarbons with photosynthetic activity, especially bromo- and iodinated compounds $0.6<r<0.9$; $(p<0.01)$ suggesting that environmental factors such as light can affect the release of these volatile halogenated compounds by the seaweeds into the atmosphere (Keng et al., 2013). The influence of irradiance on production of some halocarbons by the seaweeds may be a photosynthesis-related mechanism (Ekdahl et al., 1998; Goodwin et al., 1997; Laturnus et al., 2000), since the halocarbons may be a result of hydrogen peroxide produced by the Mehler reaction or pseudocyclic photophosphorylation during photosynthesis (Manley and Barbero, 2001; Pedersén et al., 1996). Halocarbon production in seaweeds is 
also affected by light (Mtolera et al., 1995; Nightingale et al., 1995; Laturnus et al., 2000); pH (Mtolera et al., 1995); desiccation (Leedham, 2015; Nightingale et al., 1995); oxidative stress (Abrahamsson et al., 2003); tissue age (Nightingale et al., 1995); tissue wounding / grazing (Sundström et al., 1996; Nightingale et al., 1995) and photosynthetic activity (Sundström et al., 1996; Goodwin et al., 1997).

\section{Potential Contribution of Seaweed Farms to Halocarbon Emission in the Maritime Continent}

Leedham et al. (2013) published an excellent report on halocarbon production by 15 tropical seaweeds collected in Malaysia, including the farmed seaweed, Kappaphycus alvarezii, and calculated production rates were used to estimate $\mathrm{CHBr}_{3}$ and $\mathrm{CH}$ ${ }_{2} \mathrm{Br}_{2}$ emissions for Malaysian and South East Asian coastal zones. Of the seaweeds studied, the farmed species of Gracilaria changii (1037-1272 pmol $\mathrm{gFW}^{-1} \mathrm{~h}^{-1}$ ) and Kappaphycus alvarezii (479-558 pmol $\mathrm{gFW}^{-1} \mathrm{~h}^{-1}$ ) were shown to be the amongst the highest producers of $\mathrm{CHBr}_{3}$. Leedham et al. (2013) also estimated the annual emissions of $\mathrm{CHBr}_{3}$ from Malaysia and the Southeast Asian region (SEA, comprising Brunei, Burma, Cambodia, Christmas Island, Indonesia, Malaysia, the Philippines and Singapore) based on the total coastal lengths. The estimated flux rate of 17-610 nmol $\mathrm{CHBr}_{3} \mathrm{~m}^{-2} \mathrm{~h}^{-1}$ for SEA resulted in an estimated annual emission range of 6-224 mmol Br $\mathrm{yr}^{-1}$ that was lower than that (180-350 $\left.\mathrm{mmol} \mathrm{Br} \mathrm{yr}^{-1}\right)$ reported by Pyle et al. (2011a), although the definition of SEA was not similar. Robinson et al. (2014) provided updated observations, especially of the biogenic short-lived $\mathrm{CHBr}_{3}, \mathrm{CH}_{2} \mathrm{Br}_{2}$ and $\mathrm{CHI}_{3}$, from a 15-month survey from the rainforest (Danum) and coastal (Kunak) sites first reported by John et al. (2011). Robinson et al. (2014) reported that contrary to John et al. (2011), the bromine detected at both the rainforest and coastal sites were similar, with $\mathrm{CHBr}_{3}$ and $\mathrm{CH}-$ ${ }_{2} \mathrm{Br}_{2}$ not showing seasonal variations, but short-term variations were evident in the coastal site related to the marine sources including coastal seaweed and both coastal and oceanic phytoplankton. They also stated that the overall bromine values of $8.0 \mathrm{ppt}$ and $6.8 \mathrm{ppt}$ at the coast and inland respectively, were not very different from reported tropical data. Mohd Nadzir et al. (2014) used data collected during a research cruise over the Straits of Malacca, the South China Sea and the Sulu-Sulawesi Sea in 2009, estimated a regional emission of $63 \mathrm{Ggyr}^{-1} \mathrm{CHBr}_{3}$ for the Southeast Asian region. $\mathrm{CHBr}_{3}$ was the most abundant bromocarbon, ranging from $5.2 \mathrm{pmolmol}^{-1}$ in the Straits of Malacca to 0.94 pmolmol $^{-1}$ over the open ocean. Although these figures were based on many assumptions, short-term monitoring or grab samples, they were useful for comparisons with data reported for other regions, indicating the potential importance of the tropics as a dominant source of halocarbons which are transported to the stratosphere by the intense tropical convection.

The red seaweeds Kappaphycus/Eucheuma and Gracilaria are the dominant species farmed in the Coral Triangle. Seaweed production increased tremendously from 2003 till 2012 in Indonesia (1209\% increase), Malaysia (1226\%), Vietnam (682\%) and the Philippines (77\%) (FAO, 2014). China (50\% increase) and Korea also recorded increase in seaweed production, although it was based on brown seaweeds, while Japan (-8\%) and Taiwan (-72\%) recorded great decrease in production. These figures predict upward trends in most of the countries in the Maritime Continent, and it is timely to focus more attention on the emissions of halocarbons arising from seaweed farms in the region. Green seaweeds like Caulerpa, Ulva harvested from natural populations for use as food, and the brown seaweeds Sargassum and Padina which dominate coral reefs, may also be significant contributors to the halocarbon load in the region. Keng et al. (2013) showed that the Malaysian brown seaweeds, Sargassum binderi, Turbinaria conoides and Padina australis had much higher production rates of $\mathrm{CH}_{3} \mathrm{I}_{2} \mathrm{CH}_{2} \mathrm{I}_{2}$, $\mathrm{CH}_{2} \mathrm{Br}_{2}, \mathrm{CHBr}_{3}, \mathrm{CH}_{2} \mathrm{BrI}, \mathrm{CHBr}_{2} \mathrm{Cl}, \mathrm{CH}_{3} \mathrm{BrCl}_{2}, \mathrm{CH}-$ ${ }_{2} \mathrm{BrCl}$ than the temperate and polar species.

Table 1 summarises the halocarbons emitted by selected seaweed species that are found in tropical/ sub-tropical Maritime Continent. The life-times of some of these compounds range from 7 days $\left(\mathrm{CH}_{3} \mathrm{I}\right)$ to $15-21$ days $\left(\mathrm{CHBr}_{3}\right)$ and up to 120 days $\left(\mathrm{CH}_{2} \mathrm{Br}_{2}\right)$ (Robinson et al., 2014). Dibromomethane $\left(\mathrm{CH}_{2} \mathrm{Br}_{2}\right)$ is emitted by all the seaweeds reported and it would be interesting to determine the contributions of farmed versus natural seaweed populations.

More intensive studies have to be carried out, including halocarbon emissions from more seaweed species and the mapping of both natural and farmed seaweed areas to provide better estimates of areas to be used for the estimations. The effects of ocean warming and acidification on marine algae are still 


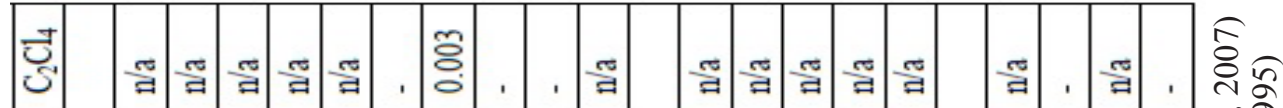

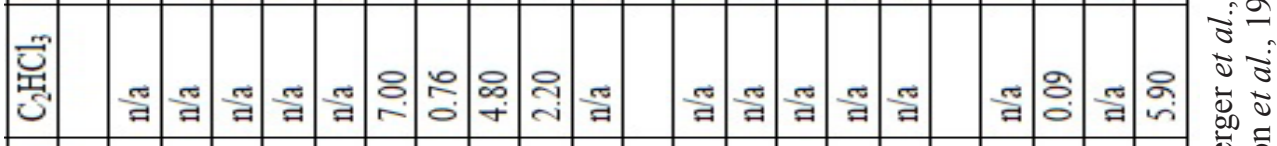

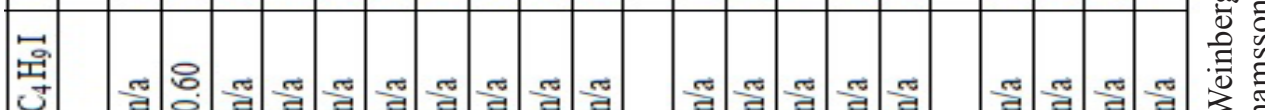
岗 త్ర

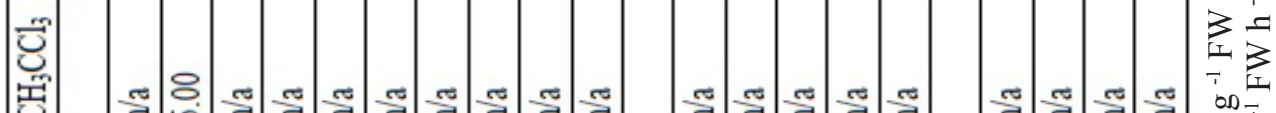

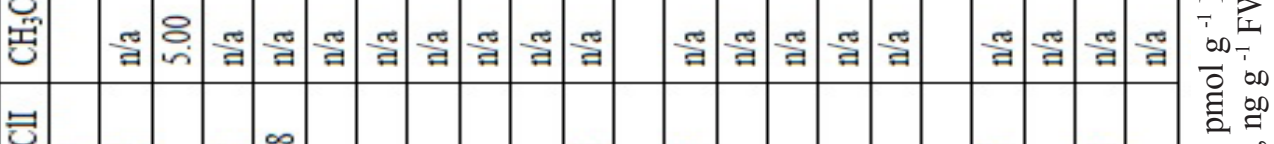

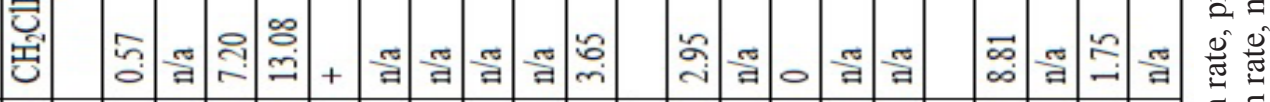

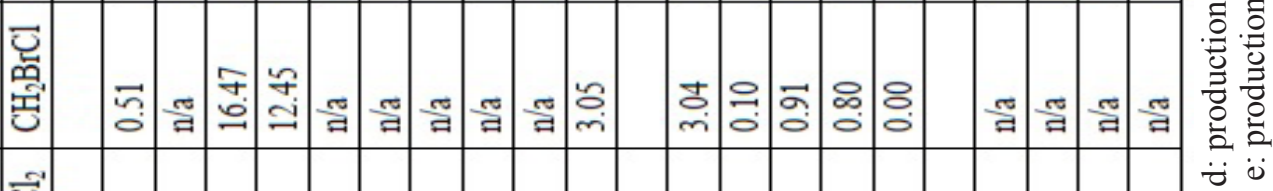

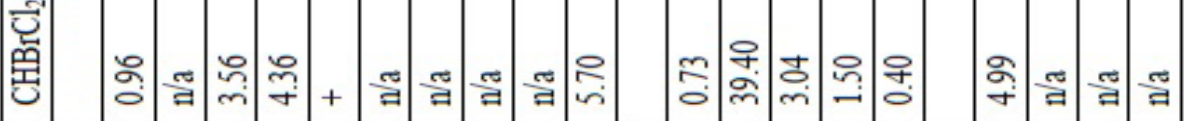

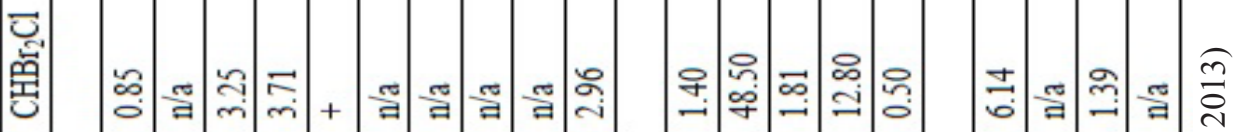

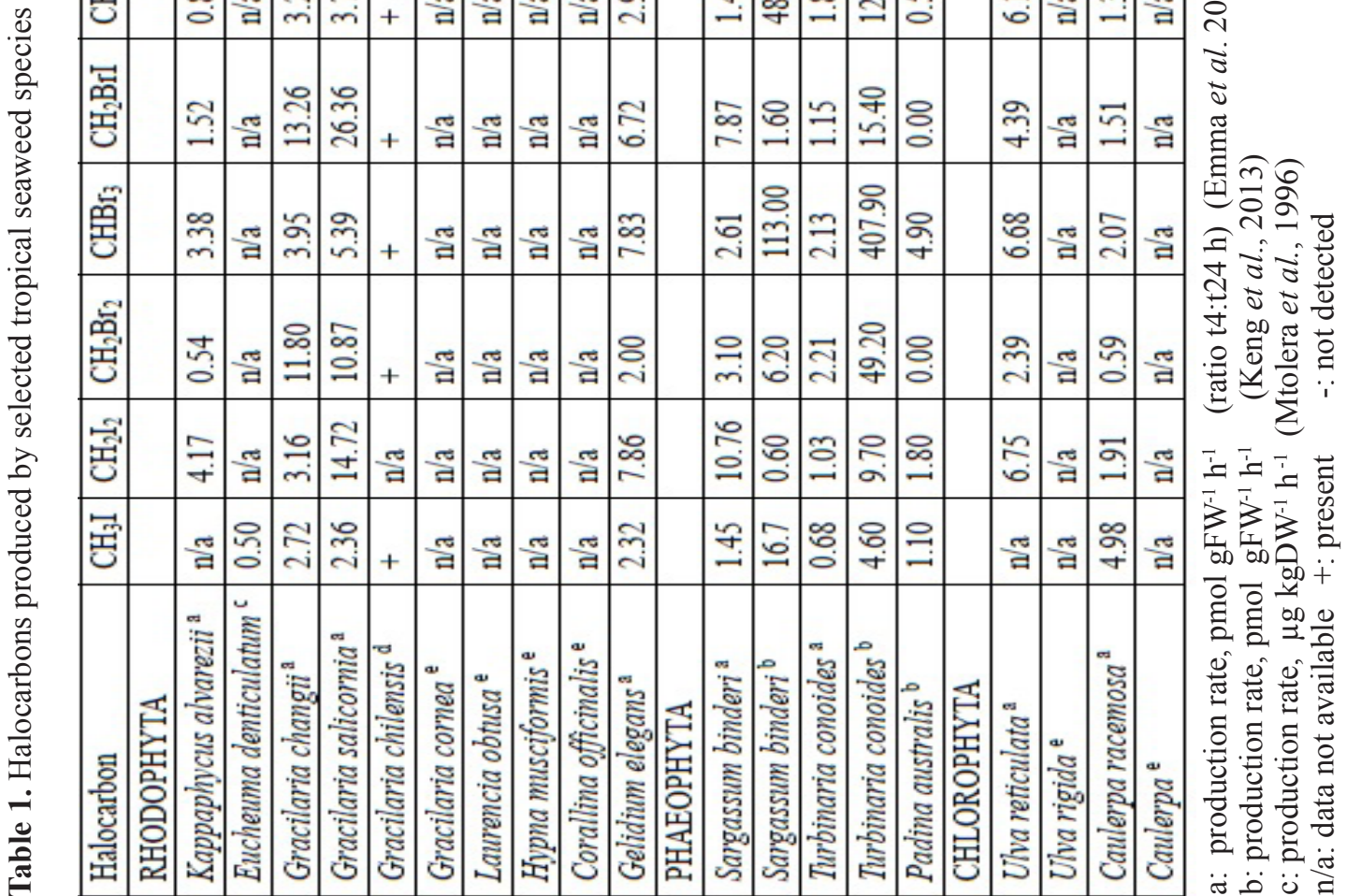


relatively undetermined, although reports indicate that the environmental stress can cause increased release of halocarbons from seaweeds. Tropical species have adapted to less variable climatic conditions than temperate species, with narrower ranges of temperature and irradiance. Our studies have shown that polar and temperate algae survive at temperatures much higher than their ambient, while the tropical algae grew best at their ambient temperature $\left(28-33{ }^{\circ} \mathrm{C}\right)$. This is probably because the tropical microalgae are already growing at their upper temperature limit (Teoh et al., 2013). Adaptation to temperature changes is related to lipid content as well as the ratio of saturated fatty acid (SFA) to unsaturated fatty acid (UFA) contents. At low temperatures, there is an increase in SFA to maintain membrane fluidity, while at increased temperature, the reverse was observed. How will temperature stress influence halocarbon production and emission in tropical seaweeds, especially under acidifying conditions?

\section{CONCLUDING REMARKS}

Recent reports show that the tropics make significant contributions of the short-lived halogenated compounds to the atmosphere, contributing to climate change, but has yet to be confirmed for the west Pacific region. Seaweed production has increased tremendously in the Coral Triangle over the last decade, and if the trend continues, farmed seaweeds may be an important source of these compounds in addition to natural populations. Attempts to estimate the annual emissions of selected compounds are based on many assumptions. To enable better estimations, efforts at profiling halocarbon emissions from the farmed seaweeds as well as dominant species along the coastal and island habitats, under various environmental conditions, have to be combined with extensive survey and mapping of natural seaweed beds to determine the species composition, distribution and relative abundance. Long-term and continuous measurements are important to provide high quality data for understanding the contribution of the tropical marine biogenic sources of the halocarbons to the atmosphere, and implications to global climate change. The atmospheric laboratory at the Institute of Ocean and Earth Sciences (IOES) Bachok Marine Research Station, Kelantan, which faces the South China Sea, has been equipped to serve the purpose of long-term and continuous monitoring of the atmospheric com- position in the region.

\section{ACKNOWLEDGEMENTS}

The submitting author would like to thank all research collaborators and postgraduate students for the useful and interesting results and discussions in their publications, that have contributed to this paper. The following research grants have supported the research that have contributed to this publication:IOES-NERC International Opportunities Fund:IF002-2013; HICoE MOE: IOES-2014F (Interaksi Udara, Darat \& Biota: Penghasilan dan emisi halokarbon daripada alga marin semasa perubahan iklim); UMRG: RG206-13SUS (The Effect Of Ocean Acidification And Temperature Change On Halocarbon Emissions By Tropical Seaweeds); FRGS: FP018-2012A (Halocarbon production by tropical seaweeds);RU006L-2014 Knowledge Management; RU009E-2015 Halocarbon emissions by tropical marine algae; RU009K-2015: Knowledge Management.

\section{REFERENCES}

1. Abrahamsson, K., and Pedersén, M. (2000). Evidence of the natural production of trichloroethylene (reply to the comment by Marshall et al.). Limnol. Oceanogr. 45: 520-522.

2. Abrahamsson, K., Ekdahl, A., Collen, J. and Pedersén, M. (1995). Marine algae - a source of trichloroethylene and perchloroethylene. Limnol. Oceanogr. 40(7): 1321-1326.

3. Abrahamsson, K., Choo, K. S., Pedersén, M., Johansson, G. and Snoeijs, P. (2003). Effects of temperature on the production of hydrogen peroxide and volatile halocarbons by brackish water algae. Phytochem. 6: 725 - 734 .

4. Ar Gall, E., Küpper, F. C. and Kloareg, B. (2004). A survey of iodine contents in Laminaria digitata. Bot. Mar. 47: 30 - 37.

5. Aschmann, J., Sinnhuber, B.M., Atlas, E.L. and Schauffler, S.M. (2009). Modeling the transport of very shortlived substances into the tropical upper troposphere and lower stratosphere. Atmos. Chem. Phys. 9(23): 9237 - 9247.

6. Barros, M.P., Necchi, O. Jr., Colepicolo, P. and Pedersén, M. (2006) stratosphereKinetic study of the plastoquinone pool availability correlat- 
ed with $\mathrm{H}^{2} \mathrm{O}^{2}$ release in seawater and antioxidant responses in the red alga Kappaphycus alvarezii exposed to single or combined high light, chilling and chemical stresses. Biochim. Biophys. Acta 1757: 1520-1528.

7. Broadbent, A.D., Jones, G.B. and Jones, R.J. (2002). DMSP in Corals and Benthic Algae from the Great Barrier Reef. Estuar. Coast. Shelf Sci. 55: 547-555.

8. Broadgate, W.J., Liss, P. and Penkett, S.A. (1997). Seasonal emission of isoprene and other reactive hydrocarbon gases from the ocean. Geophys. Res. Lett. 21(21): 2675-2678.

9. Broadgate, W.J., Malin, G., Küpper, F.C., Thompson, A. and Liss, P. (2004). Isoprene and other non-methane hydrocarbons from seaweeds: a source of reactive hydrocarbons to the atmosphere. Mar. Chem. 88: 61-73.

10. Butler, A. and Walker, J.V. (1993). Marine haloperoxidases. Chem. Rev. 93: 1937 - 1944.

11. Carpenter, L.J. and Liss, P.S. (2000). On temperate sources of bromoform and other reactive organic bromine gases. J. Geophys. Res. 105 (D16): 20539 - 20548.

12. Carpenter, L.J., Malin, G., Liss, P.S. and Küpper, F.C. (2000). Novel biogenic iodine-containing trihalomethanes and other short-lived halocarbons in the coastal East Atlantic. Global Biogeochem. Cy. 14 (4): 1191 - 1204.

13. Choo K. S., Snoeijs, P., and Pedersén M. (2004). Oxidative stress tolerance in the filamentous green algae Cladophora glomerata and Enteromorpha ahlneriana. J. Exp. Mar. Biol. Ecol. 298: 111 - 123.

14. Disch, A., Schwender, J., Muller, C., Lichtenthaler, H.K. and Rohmer, M. (1998). Distribution of the mevalonate and glyceraldehyde phosphate/pyruvate pathways for isoprenoid biosynthesis in unicellular algae and the cyanobacterium Synechocystis PCC 6714. Biochem. J. 333: 381-388.

15. Dummermuth, A.L., Karsten, U., Fisch, K.M., König, G.M. and Wiencke, C. (2003). Responses of marine macroalgae to hydrogen-peroxide stress. J. Exp. Mar. Biol. Ecol. 289: 103 - 121.

16. Ekdahl, A., Pedersén, M., and Abrahamsson,
K. (1998). A study of the diurnal variation of biogenic volatile halocarbons. Mar. Chem. 63: $1-8$.

17. FAO 2014. Fishery and Aquaculture Statistics 2012.

18. Forster, P. and Joshi, M. (2005). The role of halocarbons in the climate change of the troposphere and stratosphere. Climatic Change 71(1): $249-266$.

19. Frische, M.K., Garofalo, K., Hansteen, T.H., Borchers, R. and Harnisch, J. (2006). The origin of stable halogenated compounds in volcanic gases. Environ. Sci. Pollut. Res. 13(6): $406-412$.

20. Ganzon-Fortes, E. T. (2012). A historical account of biodiversity studies on Philippine seaweeds (1800-1999). Coast. Mar. Sci. 35(1): $182-201$

21. Goodwin, K.D., North, W.J. and Lidstrom, M.E. (1997). Production of bromoform and dibromomethane by Giant Kelp: Factors affecting release and comparison to anthropogenic bromine sources. Limnol. Oceanogr. 42:1725 -1734 .

22. Hayashi L, Bulboa C, Kradolfer P, Soriana G and Robledo D. 2014. Cultivation of red seaweeds; A Latin American perspective. J. Appl. Phycol. 269(2): 719-727

23. Hughes, C., Malin, G., Nightingale, P.D., and Liss, P.S. (2006). The effect of light stress on the release of volatile iodocarbons by three species of marine microalgae. Limnol. Oceanogr. 51(6): 2849 - 2854.

24. Hurtado, A.Q., Gerung, G.S., Suhaimi Yasir and Critchley, A.T. (2014). Cultivation of tropical red seaweeds in the BIMP-EAGA region. J. Appl. Phycol. 26(2): 707-718.

25. Keng, F.S.-L., Phang, S.-M., Abd Rahman, N., Leedham, E.C., Hughes, C., et al. (2013). Volatile halocarbon emissions by three tropical brown seaweeds under different irradiances. $J$ Appl. Phycol. 25 (5): 1377-1386, DOI 10.1007/ s10811-013-9990-x.

26. Küpper, F.C., Carpenter, L.J., McFiggans, G.B., Palmer, C.J., Waite, T.J., et al. (2008). Iodide accumulation provides kelp with an inorganic 
antioxidant impacting atmospheric chemistry. PNAS 105: 6954 - 6958.

27. La Barre, S., Potin, P., Leblanc, C. and Delgae, L. (2010). The halogenated metabolism of brown algae (Pheophyta), its biological importance and its environmental significance. Mar. Drugs 8:988-1010.

28. Laturnus, F., Haselmann, K.F., Bosch, T. and Grøn, C. (2002). Terrestrial natural sources of trichloromethane (Chloroform, $\left.\mathrm{CHCl}_{3}\right)-\mathrm{An}$ overview. Biogeochem. 60: 121 - 139.

29. Laturnus, F., Giese, B., Wiencke, C. and Adams, F.C. (2000). Low-molecular-weight organoiodine and organobromine compounds released by polar macroalgae - The influence of abiotic factors. Fresenius J. Anal. Chem. 368: $297-302$.

30. Laube, J.C., Engel, A., Bönisch, H., Möbius, T., Worton, D.R. et al. (2008). Contribution of very short-lived organic substances to stratospheric chlorine and bromine in the tropics - a case study. Atmos. Chem. Phys. 8 (23): $7325-$ 7334, DOI: $10.5194 / \mathrm{acp}-8-7325-2008$.

31. Leedham, E. C., Hughes, C., Keng, F. S. L., Phang, S.-M., Malin, G., and Sturges, W. T. (2013). Emission of atmospherically significant halocarbons by naturally occurring and farmed tropical macroalgae, Biogeosci. 10: 3615-3633, DOI:10.5194/bg-10-3615-2013.

32. Leedham Elvidge, E.C., Phang, S.-M., Sturges, W.T. and Malin, G. (2015). The effect of dessication on the emission of volatile bromocarbons from two common temperate macroalgae. Biogeosci. Discuss. 11: 10673 - 10701.

33. Levine, J.G., Braesicke, P., Harris, N. R. P., Savage, N.H. and Pyle, J.A. (2007). Pathways and timescales for troposphere-to-stratosphere transport via the tropical tropopause layer and their relevance for very short lived substances. J. Geophys. Res. 112: D04308, DOI:10.1029/ 2005Jd006940.

34. Levine, J. G., Braesicke, P., Harris, N. R. P. and Pyle, J. A. (2008) Seasonal and inter-annual variations in troposphere-to-stratosphere transport from the tropical tropopause layer. Atmos. Chem. Phys. 8: 3689-3703. (doi:10.5194/acp8-3689-2008).
35. Lewmanomont, K. and H. Ogawa, (1995). Common Seaweeds and Seagrasses of Thailand, Faculty of Fisheries, Kasetsart University, Bangkok. 154 pp.

36. Liss P. (2007). Trace gas emissions from the marine biosphere. Phil. Trans. R. Soc. A 365: 1697-1704.

37. Lovelock, J.E. (1975) Natural halocarbons in the air and in the sea. Nature 256:193-194.

38. Manley, S.L. (2002). Phytogenesis of halomethanes: a product of selection or a metabolic accident? Biogeochem. 60: 163 - 180.

39. Manley, S.L. and Barbero, P.E. (2001). Physiological constraints on bromoform $\left(\mathrm{CHBr}_{3}\right)$ production by Ulva lactuca (Chlorophyta). Limnol. Oceanogr. 46: 1392 - 1399.

40. Martinerie, P., Nourtier-Mazauric, E., Barnola, J.-M., Sturges, W.T., Worton, D.R., et al. (2009). Long-lived halocarbon trends and budgets from atmospheric chemistry modeling constrained with measurements in polar firn. Atmos. Chem. Phys. 9(12): 3911 - 3934.

41. McConnell, O. and Fenical, W. (1977). Halogen chemistry of the red alga Asparagopsis. Phytochem. 16: 1-8.

42. Mead, M.I., Khan, M.A.H., Whitem I.R., Nickless, G. and Shallcross, D.E. (2008). Methyl halide emission estimates from domestic biomass burning in Africa. Atmos. Environ. 42: $5241-5250$.

43. Mohd Nadzir, M.S., Phang, S.M., Abas, M.R., Abdul Rahman, N., Abu Samah, et al. (2014). Bromocarbons in the tropical coastal and open ocean atmosphere during the Prime Expedition Scientific Cruise 2009 (PESC 09). Atmos. Chem. Phys. 14: 8137-8148.

44. Montzka, S. A., Reimann, S., Engel, A., Kruger, K., O'Doherty, S., et al. (2010). Chapter 1. Ozone-Depleting Substances (ODSs) and Related Chemicals. In: Scientific Assessment of Ozone Depletion 2010, Global Ozone Research and Monitoring Project Report No. 52, World Meteorological Organisation, Geneva, Switzerland.

45. Mtolera, M.S.O., Collén, J., Pedersén, M., Ekdahl, A., Abrahamsson, K. and Semesi, A.K. (1996). Stress-induced production of volatile 
halogenated organic compounds in Eucheuma denticulatum (Rhodophyta) caused by elevated $\mathrm{pH}$ and high light intensities. Europ. J. Phycol. 31(1): $89-95$.

46. Mtolera, M. S. P., Collén, J., Pedersén, M. and Semesi, A. K. (1995). Destructive hydrogen peroxide production in Eucheuma denticulatum (Rhodophyta) during stress caused by elevated $\mathrm{pH}$, high light intensities and competition with other species. Europ. J. Phycol. 30(4): 289-297.

47. Msyuya, F.E., Buriyp, A., Omar, I., Pascal, B., Narrain, K. et al. (2014). Cultivation and utilization of red seaweeds in the Western Indian Ocean (WIO) Region. J. Appl. Phycol. 26(2): 699-705.

48. Neidleman, S.L. and Geigert, J. (1986). Biohalogenation: Priciples, Basic Roles, and Applications. Ellis Horwood Ltd., Chichester.

49. Neish I.C. (2008). Overview of seaweed in the world and Indonesia seaweed prospects. Paper presented at the SEABFEX 2008, Makassar, Indonesia, October 27-30, 2008.

50. Nguyen, T.V., N.H. Le, S.-M. Lin, F. Steen and O. De Clerck, (2013). Checklist of the marine macroalgae of Vietnam. Bot. Mar. 56(3): 207227.

51. Nightingale, P.D., Malin, G. and Liss, P.S. (1995). Production of chloroform and other low-molecular-weight halocarbons by some species of macroalgae. Limnol. Oceanogr. 40 (4): $680-689$.

52. Ohsawa, N., Ogata, Y., Okada, N. and Itoh, N. (2001). Physiological function of bromoperoxidase in the red marine alga, Corallina pilulifera: production of bromoform as an allelochemical and the simultaneous elimination of hydrogen peroxide. Phytochem. 58: $683-$ 692.

53. Paul, C. and Pohnert, G.(2010). Production and role of volatile halogenated compounds from marine algae. Nat. Prod. Rep. 28: 186-195, DOI:10.1039/c0np00043d.

54. Paul, N.A., de Nys, R. and Steinberg, P.D. (2006). Chemical defense against bacteria in the red alga Asparagopsis arnata: linking structure with function. Mar. Ecol. Progr. Ser.
306: $87-101$.

55. Pedersén, M., Collén, J., Abrahamsson, K., and Ekdahl, A. (1996). Production of halocarbons from seaweeds: an oxidative stress reaction? Sci. Mar. 60: 257-263.

56. Pfeilsticker, K., Dorf, M., Sturges, B., Oran, D., Engel, A., et al. (2013). The SHIVA Western Pacific Campaign in Fall 2011. Malaysian J. Sci. 32: 141-148.

57. Pham, M. N., Tan, H.T.W., Mitrovic,S. and Yeo, H. H. T. (2011). A Checklist of the Algae of Singapore, 2nd Edition. Raffles Museum of Biodiversity Research National University of Singapore, Singapore ISBN 978-981-07-01833.

58. Phang, S.M. (1995). Distribution and abundance of marine algae on the coral reef flats at Cape Rachado, Peninsular Malaysia. Malaysian J. Sci. 16A: 23-32.

59. Phang, S.M., Lim, P.E. and Yeong, H.Y. (2010). Malaysian Seaweed Resources in the South China Sea and their Potential Economic and Ecological Applications. J. Sci. \& Tech. in the Tropics 6 (2): 87-109.

60. Pyle, J.A., Ashfold, M.J., Harris, N.R.P., Robinson, A.D., Warwick, N.J et al. (2011a). Bromoform in the tropical boundary layer of the Maritime Continent during OP3. Atmos. Chem. Phys. 11: 529-542.

61. Pyle, J.A., Warwick, N.J., Harris, N.R.P., Mohd Radzi Abas, Archibald, A.T. et al. (2011b). The impact of local surface changes in Borneo on atmospheric composition at wider spatial scales: coastal processes, land-use change and air quality. Phil. Trans. R. Soc. B 336: 3210322.

62. Robinson, A.D., Harris, N.R.P., Ashfold, M.A., Gostlow, B., Warwick, N.J. et al. (2014). Longterm halocarbon observations from a coastal and an inland site in Sabah, Malaysian Borneo. Atmos. Chem. Phys. 14: 8369-8388.

63. Shaw, S.L., Chisholm, S.W. and Prinn, R.G. (2003). Isoprene production by Prochlorococcus, a marine cyanobacterium, and other phytoplankton. Mar. Chem. 80: 227-245.

64. Sundström, J., Collén, J., Abrahamsson, K. and 
Pedersén, M. (1996). Halocarbon production ad in vivo brominating activity of Eucheuma denticulatum. Phytochem. 42(6): 15527 - 1530.

65. Teoh, M.-L., Phang, S.-M. and Chu, W.-L. (2013). Response of Antarctic, temperate, and tropical microalgae to temperature stress. $J$. Appl. Phycol. 25: 285-297.

66. Tokarczyk, R. and Moore, R.M. (1994). Production of volatile organohalogens by phytoplankton cultures. Geophys. Res. Lett. 21: 285-288.

67. UNEP/TEAP (United Nations Environment Programme/Technology and Economic Assessment Panel). (2010). Report of the Technology and Economic Assessment Panel (TEAP), Progress report, Volume 2, coordinated by L. Kuipers and M. Seki, Nairobi, Kenya.

68. Varaippan, C.S. (2003). Potent antibacterial activity of halogenated metabolites from Malaysian red algae, Laurencia majuscula (Rhodomelaceae, Ceramiales). Biomol. Eng. 20: 255-259.

69. Vairappan, C.S., Ang, M.Y., Ong, C.Y. and Phang, S.M. (2004). Biologically active polybrominated indoles in the red alga Laurencia similis from the coastal waters of Sabah (Rhodomelaceae, Ceramiales). Malaysian J. Sci. 23 (2): 119-126.

70. Varaippan, C.S. and Phang, S.M. (2005) Morphology and Halochamegrene Metabolite Content of Laurencia majuscule (Rhodomelaceae, Ceramiales) from the Spratly Islands. Malaysian J. Sci. 24(2): 29-36.

71. Vairappan, C.S., Suzuki, M., Ishii, T., Okino, T., Abe, T. and Masuda M. (2008). Antibacterial activity of halogenated sesquiterpenes from Malaysia Laurencia spp. Phytochem. 69: 24902494.
72. Verheij, E. and Prud'homme van Reine, W.F. (1993). Seaweeds of the Spermonde Archipelago, SW Sulawesi, Indonesia. Blumea 37: 385-510.

73. Weinberger, F., Coquempot, B., Forner, S., Morin, P., Kloareq, P. et al. (2007). Different regulation of haloperoxidation during agar oligosaccharide-activated defence mechanisms in two related red algae, Gracilaria sp. and Gracilaria chilensis. J. Exp. Bot. 58 (15/16): 4365 -4372 .

74. Williams, J., Gros, V., Atlas, E., Maciejczyk, K., Batsaikhan, A. et al. (2007). Possible evidence for a connection between methyl iodide emissions and Saharan dust. J. Geophys. Res. 112 (D07302), DOI: 10.1029/2005JD0006702.

75. WMO (World Meteorological Organization). (2007). Scientific Assessment of Ozone Depletion: 2006, Global Ozone Research and Monitoring Project - Report No. 50, World Meteorological Organisation, Geneva, Switzerland.

76. WMO (World Meteorological Organization). (2011). Scientific Assessment of Ozone Depletion: 2010, Global Ozone Research and Monitoring Project-Report No.52, World Meteorological Organisation, Geneva, Switzerland.

77. Wuosmaa, A.-M. and Hager, L.P. (1990).

Methyl Chloride Transferase: A carbocation route for biosynthesis of halometabolites. Sci. 249: $160-162$.

78. WWF (World Wide Fund for Nature) (2015). Problems in the Coral Triangle. Link source: http://wwf.panda.org/what_we_do/where_we work/coraltriangle/problems/

79. Yokouchi, Y., Osada, K., Wada, M., Hasebe, F., Agama, M. et al. (2008). Global distribution and seasonal concentration change of methyl iodide in the atmosphere. J. Geophys. Res. 113(D18311), DOI: 10.1029/2008JD009861. 